\title{
Survey of Status for Ageing Population, Charge Organizations and Polices in UK
}

\section{Dohyung Kee}

Department of Industrial and Management Engineering, Keimyung University, Daegu, 704-701

\author{
Corresponding Author \\ Dohyung Kee \\ Department of Industrial and \\ Management Engineering, Keimyung \\ University, Daegu, 704-701 \\ Mobile : +82-10-5656-1260 \\ Email : dhkee@kmu.ac.kr
}

Received : September 02, 2014

Revised : October 01, 2014

Accepted: October 16, 2014
Copyright@2014 by Ergonomics Society of Korea. All right reserved.

(c) This is an open-access article distributed under the terms of the Creative Commons Attribution Non-Commercial License (http:// creativecommons.org/licenses/by-nc/3.0/), which permits unrestricted non-commercial use, distribution, and reproduction in any medium, provided the original work is properly cited.
Objective: The purpose of this study is to survey trend and the real state of ageing population in UK, and its charge organizations, relevant policies and studies.

Background: As in other countries, UK population is ageing and people aged 65 or over account for about $17 \%$ of population in UK. Considering this ageing population, there are varying basic studies and policies for older people in UK.

Method: First, the author consulted ageing and its policies in UK with some faculties in an UK university. Next, based on the results of consultation, wide literature survey was conducted, which includes papers in relevant academic journals, publications and website surfing.

Results: A number of basic studies for surveying status and characteristics of older people as well as simple population trend for them have been conducted in UK. Healthcare services are free for all UK residents, and varying social care services including equipment, home and residential cares, financial support, etc., are provided by local governments. Cost of social cares is means-tested and is not free for everyone. There are a number of governmental or non-profit organizations dedicated to help older people access social care services or to financially fund research projects older people.

Conclusion: There are more basic studies, and healthcare and social care services for older people in UK, compared to Korea.

Application: It would be useful as basic data for establishing effective polices for old people in Korea.

Keywords: Ageing, Ageing population, Ageing policies, Healthcare and social care

\section{Introduction}

The population of most countries is aging, especially in Korea., which is brought by a combination of longer life expectancy, declining fertility and progression through life of a large 'baby boom' generation. In the USA, over the past 30 years there has been a doubling of the number of workers aged 65 and older (BLS, 2014a). In addition, more and more older workers are choosing to remain in the labor force rather than retire (Toossi, 2005). In the European countries, the population of older people in working populations is increasing more than in other continents (Dul et al., 2012). In Korea, ageing population is rapidly increasing. As a result, Korea entered the ageing society in 2000 that people aged 65 or over exceeds $7 \%$ of whole 
population, and is projected to enter the society of advanced age in 2018 that people aged 65 and above exceeds $14 \%$ of whole population (Kee et al., 2006).

There is evidence of age-related changes in physiology and cognition such as reduction in muscle strength, prevalence, joint flexibility, postural stability, hand dexterity and functions of sensing, perception, cognition and tactile sensation (Intolo et al., 2009; Masani et al., 2007; Popkin et al., 2012). It has also been reported that low back pain prevalence is higher in older people (Hoy et al., 2010; Manchikanti, 2000). With the increased number of older workers, the prevalence of severe workplace injuries will likely increase since the median lost workdays per injury increases with age (BLS, 2014b). In this situation, a problem is that although a large group of older humans have become part of work and product/service systems, environments that were designed for the current group of humans may not be as suitable for elderly people in the system.

Different measures for older people including governmental policy, ergonomic design of product/service and equipment, etc., are needed, compared to other age groups. Relevant data or policies of advanced countries would be very helpful in establishing policies for older people in Korea. Ageing is one of the global trends regarding changes that impact ergonomics (Dul et al., 2012). This study surveyed trend and real state of ageing population, its charge organizations, relevant policies and researches in UK.

\section{Method}

This study was conducted mainly based on literature survey, which includes papers in relevant academic journals, publications by UK government, its affiliations, non-profit organizations and private companies, and materials found in websites. Before the literature survey, the author consulted ageing and its policies in UK with some faculties having interest in ageing in Design School, Loughborough University of UK. The faculties gave the author some useful information on policies, publications, websites, etc., which were used as the basis of the literature survey.

\section{Results}

\subsection{Trend and status of ageing population}

In UK, more than 400 surveys for lifestyle, quality of life, illness, care, dying, money matters, etc. as well as population trend for people aged 65 or over have been searched, which are thought to be used in establishing relevant policies. Of these, important data abstracted from the surveys were summarized in Table 1 (ageUK, 2014b; Office for National Statistics, 2014). Each finding in Table 1 is a result from an independent survey.

Table 1. Important findings for people aged 65 and above

\begin{tabular}{|c|c|}
\hline Category & Content \\
\hline Population & $\begin{array}{l}\text { - For the first time in history, there are } 11 \text { million people aged } 65 \text { or over in the UK in } 2013 \text {, which account } \\
\text { for about } 17 \% \text { of UK population } \\
\text { - The number of people aged } 65+\text { is projected to rise by nearly } 50 \%(48.7 \%) \text { in the next } 17 \text { years to over } 16 \\
\text { million } \\
\text { - } 3.8 \text { million } 65+\text { live alone. This is } 36 \% \text { of all people aged } 65+\text { in GB } \\
\text { - Black and minority ethnic (BME) groups make up over } 16 \% \text { of the population of England, but } 8 \% \text { of people } \\
\text { in England aged } 60 \text { and over }\end{array}$ \\
\hline
\end{tabular}


Table 1. Important findings for people aged 65 and above (Continued)

\begin{tabular}{|c|c|}
\hline Category & Content \\
\hline Lifestyle & $\begin{array}{l}\text { - Women aged } 65+: 32 \% \text { are of normal } \mathrm{BMI}, 32 \% \text { 'overweight', and } 34 \% \text { 'obese'. For men this age: only } \\
16 \% \text { are within normal } \mathrm{BMI}, 54 \% \text { are overweight, and } 31 \% \text { obese } \\
\text { - } 36 \% \text { of older men and } 39 \% \text { of older women have normal, untreated blood pressure } \\
\text { - Of those aged } 65 \text { and over who do sport, the most popular are recreational walking (10\%), swimming } \\
(6 \%) \text { and bowls }(5 \%) \\
\text { - Over } 1 \text { million older people say they are always or often feel lonely }\end{array}$ \\
\hline Quality of life & $\begin{array}{l}\text { - In the UK, } 11 \% \text { of older people describe their quality of life as very poor, quite poor or neither good nor } \\
\text { poor } \\
\text { - } 24 \text { per cent of older people in the UK reported that their quality of life had got worse over the last year, } \\
\text { whereas } 9 \text { per cent said it had improved } \\
\text { - However, } 24 \% \text { of people over } 65 \text { said they were very satisfied with their health, and } 51 \% \text { said they were } \\
\text { fairly satisfied }\end{array}$ \\
\hline Illness & $\begin{array}{l}\text { - An estimated } 4 \text { million older people in the UK ( } 36 \% \text { of people aged } 65-74 \text { and } 47 \% \text { of those aged } 75+\text { ) } \\
\text { have a limiting longstanding illness. This equates to } 40 \% \text { of all people aged } 65+ \\
\text { - } 50-70 \% \text { of women will have an osteoporotic fracture at some time } \\
\text { - } 13 \% \text { of people aged } 65+\text { have difficulties with their eyesight } \\
\text { - About } 6.4 \text { million people aged } 65+\text { have some form of hearing loss; around } 685,000 \text { of these are } \\
\text { severe/profound } \\
\text { - There are over } 2.5 \text { million people over } 60 \text { suffering from urinary incontinence in the UK, and the majority } \\
\text { are women } \\
\text { - Dementia is one of the main causes of disability in later life, ahead of some cancers, cardiovascular } \\
\text { disease and stroke }\end{array}$ \\
\hline Home and care & $\begin{array}{l}\text { - Approximately } 30 \% \text { of people use some form of local authority funded social care in } 2009 \\
\text { - In England, } 417,910 \text { people aged } 65+\text { received community-based care and support at home in 2012/13 }\end{array}$ \\
\hline Dying & $\begin{array}{l}\text { - Research suggests that the most preferred place to die is at home; hospital is the least preferred place } \\
\text { - Of people over } 65 \text { who died, } 18 \% \text { died at home, compared to } 31 \% \text { of people aged } 15-64\end{array}$ \\
\hline Money matters & $\begin{array}{l}\text { - } 1.6 \text { million pensioners (13\%) live below the poverty line, with incomes less than } £ 224 \text { per week after } \\
\text { housing costs } \\
\text {-Average weekly expenditure for households headed by someone aged between } 65 \text { to } 74 \text { is } £ 410 \text {. }\end{array}$ \\
\hline
\end{tabular}

\subsection{Governmental organizations}

There are three major governmental organizations to carry out policies related to older people in UK. Financial policies such as pension are under the jurisdiction of Department of Work and Pensions, and healthcare services are under Department of Health. Social care services such as home care, bus pass, etc. are in charge of local governments.

\subsection{Retirement and pension age}

Default retirement age (formerly 65), which was implemented in 2006, has been phased out from October 2011. Now retirement age is when an employee chooses to retire. Most businesses are no longer allowed to set a compulsory retirement age for their employees. However, some employers can set a compulsory retirement age if they can clearly justify it (UK government, 2014; ageUK, 2014a).

Retirement age is not the same as state pension age depending when someone was born and if they're male or female (UK 
government, 2014). Now, the age at which UK people can claim their state pension benefits is 65 for men and 60 for women. But huge jumps in life expectancy have seen costs shoot up, which is paying some pensioners for more years in retirement than they spent paying National Insurance as workers. The UK government will be linking the state pension age to life expectancy. This will see those in their early 20s now have to wait until they are at least 70 before they can take their state pension. In more detail, pension age is projected to hit 66 for men and women in 2020, and to rise to 67 for men and women in 2026-2028 (This is Money, 2014).

\subsection{Age discrimination act}

Since October 2006, it has been unlawful for employers and others to discriminate against a person on the basis of his/her age. The original 2006 Regulations have now been incorporated into the Equality Act 2010 (LaterLife, 2014).

\subsection{Health and social care services}

\subsubsection{Healthcare services}

The National Health Service (NHS), which is an affiliated organization of Department of Health, provides all residents including foreigners in UK as well as older people with free healthcare services. There are four publicly funded healthcare systems in UK, which include NHS (England), Health and Social Care in Northern Island, NHS Scotland and NHS Wales, but the four systems may be referred to as the NHS. The four systems are mostly independent from each other although some functions might be routinely performed on behalf of the UK Department of Health or for one of the other three systems. The systems are primarily funded through central taxation. They provide a comprehensive range of health services, the vast majority of which are free at the point of use for people legally resident in UK only to register a GP (general practitioner) near their home, which are nationally distributed (Wikipedia, 2014).

\subsubsection{Social care services}

\section{Social care services}

Social care and support services might typically include: equipment, help in your home or in a care home, community support and activities, day centers, home adaptations, residential care, financial support, information and advisory services, and advocacy, support for carers, etc (NHS, 2014).

\section{Procedure to get care}

The first step should be to ask your local authority social services department for an assessment of your needs. There are a number of organizations that can help you access these services such as Disability Rights UK, AgeUK, Scope or Mencap. Local authorities have a duty to assess anyone who appears to need the community care services they offer. Each local authority has its own way of working out who is eligible for social care support and what services it can offer.

If the local authority thinks you are eligible for social care support, they have a specific level of need and meet financial rules, you should be involved in the decision-making process that follows. If appropriate, the next step will be for social services or an independent adviser to work with you to create a care plan (ageUK, 2014a; NHS, 2014).

\section{Cost of care}

Care and support services are means-tested and are not free to everyone. Most people have to pay something towards their own care and some will have to pay for all of the costs. Who pays depends on what your needs are, how much money you have, and 
what level and type of care and support you require. You may need to pay for all of your own care, or you may be entitled to local authority funding, NHS care (free) or have entitlements to welfare benefits to help pay for your care and support (ageUK, 2014a; NHS, 2014). It was shown in Table 1 that approximately 30\% of people use some form of local authority funded social care in 2009.

\subsubsection{Bus pass and TV license}

Older and disabled people are entitled to a free bus pass and a minimum concession of free off-peak travel on a local bus anywhere in England. If a person was born before 5 April 1950, he or she is eligible from his or her 60th birthday. If a person was born after 5 April 1950, the age of eligibility for women will be pension age and for men the pensionable age of a woman born on the same day (Somerset County Council, 2014). The Senior Railcard is also available to anyone aged 60 or over, which can be ordered online from the Senior Railcard website or buy railcard from most staffed railway stations. The Senior Railcard and Disabled Persons Railcard are annual savings cards that can be purchased for a one-off cost that allow senior or disabled person to make big savings on most rail fares in the UK (ageUK, 2014c). Anyone aged 75 or over is eligible for a free TV Licence for their main address, which can be applied online or by phone. There are currently almost four million free TV Licences in force (TV Licensing, 2014).

\subsection{Other organizations for social cares}

There are some nonprofit organizations or programs for older people. TAEN in the UK is a unique independent not-for-profit organization whose primary aim is to ensure older workers have the opportunity to learn, work and earn. TAEN informs and advocates for effective age management policies to be adopted at all levels - in employing organisations, by individuals and across the labour market (TAEN, 2014). The NDA (New Dynamics of Ageing Programme) is an eight year multidisciplinary research initiative with the ultimate aim of improving quality of life of older people. The programme is a unique collaboration between five UK Research Councils - ESRC, EPSRC, BBSRC, MRC and AHRC - and is the largest and most ambitious research programme on ageing ever mounted in UK (NDA, 2014). Representative projects supported by NDA include: ageing and biology, ageing and fiction, ages and stages, CALL-ME project, cardiovascular ageing, cell ageing, design for ageing well, kitchen living, music for life, etc.

Together with governmental organizations, there are also some private companies to assist and to provide healthcare and social care services such as Care UK, Advantage, LaterLife, etc.

\section{An Example of NDA Projects: Workinglate}

Workinglate was a four-year collaborative research project beginning from 2009. The project was conducted by School of Sport, Exercise and Health Science, and Department of Human Science, Loughborough University of UK, and funded under NDA programme. The purpose of the project was to develop strategies to enhance productive and healthy environments for the older workforce. The project consisted of four main parts: New dynamics of later life working, Interventions to promote health and workability, Ageing productively through design and Improving the journey to work (Workinglate, 2014).

In new dynamics of later life working, 110 interviews were carried out with employees over 50 years of age (51), employers (20), job seekers over 50 years of age (27), and recently retired individuals (12). These explored the benefits and obstacles to working up to and beyond state pension age in light of recent policy changes including: increases in state pension age, changes in public and private sector pensions, the removal of the default retirement age, new age discrimination legislation, and an increase in high profile age discrimination cases. 
In interventions to promote health and workability, originally 1,120 individuals from public and private sectors companies were recruited for this project. These individuals were followed up at six monthly intervals, monitoring physiological and psychological changes. An intervention of 'Walking Lunch maps' have been also implemented in six organisational sites to promote incidental activity in the workplace.

In ageing productively through design, for exploring and co-developing solutions to workplace design issues, a questionnaire survey of 21 organisations and in-depth data collection for four organisations, which included interviews, ergonomics observations and focus groups, were conducted. As a result, the Organiser for Working Late (OWL) design resource was presented in two sections; "The body at work" and "Workplace design \& healthy ageing". The OWL resource aimed to support line managers in facilitating healthy ageing at work through design. An example of the OWL is shown in Figure 1.

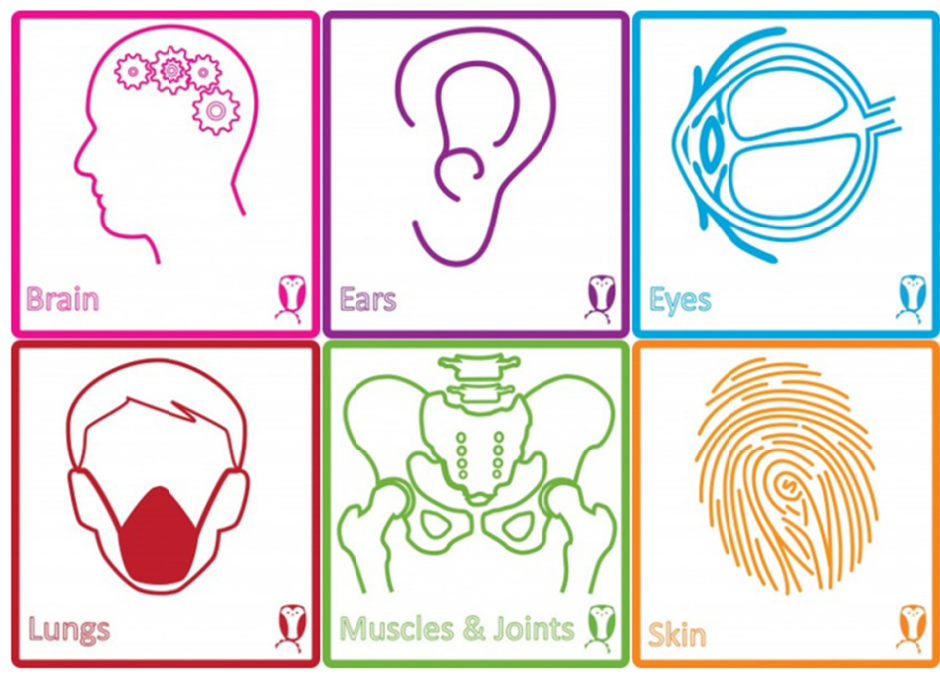

Figure 1. An example of OWL: Body@work cards

Based on research conducted with ordinary people, the section of improving the journey to work identified and presented the problems that people had with the journey to work. The information was divided into different issue categories and listed different strategies that people might find helpful to improve their journey to work. The categories were: driving issues, public transport issues, cycling \& walking issues for cycling or walking to work, road works \& issues, personal issues such as stress, health, etc., place of work issues which affect the journey to work, etc.

\section{Discussion and Conclusions}

This study surveyed and summarized trend and status of ageing population and policies or services for older people in UK, which also included governmental and private organizations in charge of the policies, retirement and pension ages, relevant studies. In addition, an example of the projects funded by NDA, which developed strategies for enhancing productive and healthy environments for older workforce, was briefed. The major findings are: 1) A number of studies for the real state and characteristics of older people as well as simple population trend for them have been conducted; 2 ) Reflecting ageing trend of population, UK government abolished the default retirement age of 65 , which enables most people to work for as long as they want to, and legislated the Age Discrimination Act in 2006 to protect older people against discrimination based on their ages, and 
due to financial pressure, pension age is also planned to rise gradually by 5-10 years in the future; 3) Healthcare services are free for all UK residents, and varying social care services including equipment, home and residential cares, financial support, etc., are provided by local governments. Cost of social cares is dependent on his/her financial status and what level and type of care is required; and 4) There are a number of governmental or non-profit organizations dedicated to help older people access social care services or to financially fund research projects for older people.

Policies or services for older people in UK, which is known one of the advanced countries where the social security system is well-established, are worthy of our country's benchmarking. On the basis of the findings, it is suggested that as in UK, retirement age be extended in phases, and that varying basic studies for surveying exact status of older people be performed for establishing proper and effective policies for older people in Korea. It would be helpful to found governmental or non-profit organizations such as ageUK, NDA, etc., which act or assist to act older people relevant policies on behalf of government or financially support research projects.

\section{References}

AgeUK, Default Retirement Age, http://www.ageuk.org.uk/work-and-learning/ discrimination-and-rights/default-retirement-age--frequently-asked-questions/ (retrieved August 27, 2014a)

AgeUK, Later life in the United Kingdom, ageUK, 2014b.

AgeUK, Public transport and concessions, http://www.ageuk.org.uk/money-matters/claiming-benefits/public-transport-andconcessions/ (retrieved August 27, 2014c).

BLS, BLS Spotlight on Statistics: Older Workers, http://bls.gov/spotlight/2008/older_workers/ (retrieved August 25, 2014a).

BLS, Nonfatal Occupational Injuries and IIInesses Requiring Days Away from Work, 2009. http://bls.gov/spotlight/2008/older_workers/ (retrieved August 25, 2014b).

NDA, View all projects, http://newdynamics.group.shef.ac.uk/ (retrieved August 27, 2014).

Dul, J., Bruder, R., Buckle, P., Carayon, P., Falzon, P., Marras, W., Wilson, J.R. and van der Doelen, B., A strategy for human factors/ ergonomics: developing the discipline and profession, Ergonomics, 55(4), 377-395, 2012.

Hoy, D., Brooks, P., Blyth, F. and Buchbinder, R., The epidemiology of low back pain, Best Practice \& Research Clinical Rheumatology, 24(6), 769-781, 2010.

Intolo, P., Milosavljevic, S., Baxter, D.G., Carman, A.B., Pal, P. and Munn, J., The effect of age on lumbar range of motion: a systematic review, Manual Theraphy, 14(6), 596-604, 2009.

Kee, D., Lee, K.T., Park, J.H. and Choi, K, Ergonomics for industrial safety managers and hygienists, $3^{\text {rd }}$ ed., Hankyung-sa, 2006.

LaterLife, The Age Discrimination Legislation and how it Affects Employers, http://www. laterlife.com/laterlife -age -discriminationlegislation-employers.htm (retrieved August 27, 2014).

Manchikanti, L., Epidemiology of low back pain, Pain Physician, 3(2), 167-192, 2000. 
Masani, K., Vette, A.H., Kouzaki, M., Kanehisa, H., Fukunaga, T. and Popovic, M.R., Larger center of pressure minus center of gravity in the elderly induces larger body acceleration during quiet standing, Neuroscience Letter, 422(3), 202-20, 20076.

NHS, How do / get care?, http://www.nhs.uk/CarersDirect/social-care/Pages/how-to-get-care.aspx (retrieved August 27, 2014).

Office for National Statistics, Population, http://ons.gov.uk/ons/taxonomy/index.html?nscl=Population (retrieved August 27, 2014).

Popkin, S.M., Morrow, S.L., Di Domenico, T.E. and Howarth, H.D., Age is more than just a number: Implications for an aging workforce in the US transportation sector, Applied Ergonomics, 39, 542-549, 2008.

Somerset County Council, Apply for a concessionary bus pass, http://www.somerset.gov.uk/roads-parking-and-transport/pub lic-transport/apply-for-a-concessionary-bus-pass/ (retrieved October 1, 2014).

TAEN, About us, http://taen.org.uk/about (retrieved August 27, 2014).

This is Money, New state pension age, http://www.thisismoney.co.uk/money/pensions/article-1679780/New-state-pension-ageretire.html (retrieved August 27, 2014).

Toossi, M., Labor force projections to 2014: retiring boomer,. Monthly Labor Review, 25-44, 2005.

TV Licensing, Free TV Licence for over-75s, http://www.tvlicensing.co.uk/about/media-centre/news/free-tv-licence-for-over75sNEWS58 (retrieved October 1, 2014).

UK government, Retirement age, https://www.gov.uk/retirement-age (retrieved August 27, 2014).

Wikipedia, National Health Service, http://en.wikipedia.org/wiki/National_Health_Service (retrieved August 27, 2014).

Workinglate, Welcome, http://www.workinglate.org/ (retrieved August 27, 2014).

\section{Author listings}

Dohyung Kee: dhkee@kmu.ac.kr

Highest degree: Ph.D., Department of Industrial Engineering, POSTECH

Position title: Professor, Department of Industrial and Management Engineering, Keimyung University

Areas of interest: Systems ergonomics, Population stereotype, Product design, Posture classification scheme, Industrial safety, Musculoskeletal disorders 